\title{
Study find that COVID ARDS was associated with a low risk for possible or proven PCP: still true after dexamethasone use
}

\author{
Patrick M. Honore ${ }^{1 *}$, Sebastien Redant ${ }^{2}$, Thierry Preseau ${ }^{3}$, Keitiane Kaefer ${ }^{2}$, Leonel Barreto Gutierrez ${ }^{2}$, \\ Sami Anane ${ }^{2}$, Rachid Attou ${ }^{2}$, Andrea Gallerani ${ }^{2}$ and David De Bels ${ }^{4}$
}

Keywords: COVID ARDS, PCP, Dexamethasone, High occurrence

Razazi et al. conclude that in their study of patients with COVID acute respiratory distress syndrome (ARDS), they found a low risk for possible or proven Pneumocystis jirovecii pneumonia (PCP) [1]. Their findings are in accordance with two smaller studies in France [1] retrieving a low risk of pneumocystis colonization in COVID-19 patients [1]. In their limitation section nothing was said about the fact that none of these COVID patients did receive dexamethasone [1]. We would like to comment as indeed the adjunction of dexamethasone has completely changed the occurrence of COVID-19-associated opportunistic infections including PCP [2]. Coinfection of PCP and COVID-19 has been reported in some patients with COVID-19 till now [2], in which most of them received immunosuppressive therapies, such as corticosteroids [2]. The case reports and reviews are extremely numerous with the use of dexamethasone regarding co-infection of COVID-19 and PCP [2]. Chong et al. reviewed 12 cases of COVID-19 and PCP coinfection [3]. Accordingly, all PCP infections were reported in critically ill patients with COVID-19, which most of them were upon long-term exposure to immunosuppressants $(91.7 \%, 11 / 12)$, such

This comment refers to the article available online at https://doi.org/10.1186/ s13054-021-03767-3.

*Correspondence: Patrick.Honore@CHU-Brugmann.be

' ICU Department, Centre Hospitalier Universitaire Brugmann-Brugmann

University Hospital, ULB University, Place Van Gehuchtenplein, 4,

1020 Brussels, Belgium

Full list of author information is available at the end of the article as high-dose corticosteroids [3]. Numerous cases were also diagnosed after post-mortem examination [3]. Since $\mathrm{PCP}$ is usually reported in patients with T-cell immunodepression, less attention has been paid to PCP in nonimmunocompromised intensive care unit (ICU) patients although it accounts for $7 \%$ of the co-infections reported in those admitted with Influenza [4]. After the use of dexamethasone in COVID-19 ARDS, these researchers did find an unexpectedly high proportion of ICU COVID19 patients detected with PCP (10/108 patients; 9.3\%) [4]. According to their unexpectedly high proportion of pneumocystis-positive pulmonary samples observed in ICU COVID-19 patients and based on their findings, they advocate systematically searching for pneumocystis in deep respiratory specimens in these patients [4]. They believe that this strategy may be useful in limiting enhanced inflammation due to the presence of pneumocystis in the lung and avoiding inter-patient pneumocystis transmission [4]. It stands to reason that the statement by Razazi et al. that in their study of patients with COVID ARDS, they found a low risk for possible or proven PCP is no longer valid as the systematic use of dexamethasone has increased to an unexpectedly high proportion of ICU COVID-19 patients detected with $P$. jirovecii [4]. It remains somewhat strange that Razazi et al. were not expecting high levels of co-infection of COVID ARDS and PCP after the systematic use of dexamethasone.

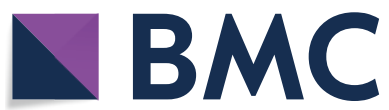

(c) The Author(s) 2022. Open Access This article is licensed under a Creative Commons Attribution 4.0 International License, which permits use, sharing, adaptation, distribution and reproduction in any medium or format, as long as you give appropriate credit to the original author(s) and the source, provide a link to the Creative Commons licence, and indicate if changes were made. The images or other third party material in this article are included in the article's Creative Commons licence, unless indicated otherwise in a credit line to the material. If material is not included in the article's Creative Commons licence and your intended use is not permitted by statutory regulation or exceeds the permitted use, you will need to obtain permission directly from the copyright holder. To view a copy of this licence, visit http://creativecommons.org/licenses/by/4.0/. The Creative Commons Public Domain Dedication waiver (http://creativeco mmons.org/publicdomain/zero/1.0/) applies to the data made available in this article, unless otherwise stated in a credit line to the data. 


\section{Authors' response}

\section{Romain Arrestier, Armand Mekontso-Dessap, Francoise Botterel and Keyvan Razazi}

To the Editor,

We thank Honore and colleagues for their comments on our research letter about low risk of Pneumocystis pneumonia in COVID-19 patients with acute respiratory distress syndrome (ARDS).

We point out in the discussion that patients of our cohort were included before the systematic use of dexamethasone, but we may not have sufficiently discussed it.

Enrolment of patients during the first wave is indeed a limitation of our study because of the lower use of corticosteroid therapy compared to the other waves. To explore further this potential bias, we analysed 239 consecutive COVID-19 patients, hospitalized in our intensive care unit during the following waves from 26th May 2020 to 11th April 2021 (Anticovid study Clinical trials NCT04433105). All were treated with corticosteroids, 39 (16.3\%) with tocilizumab and 29 (12.1\%) were immunocompromised.

Of these, 73 had a Pneumocystis examination, including 131 PCR and 107 direct examinations (43 May Grunwald Giemsa stainings and 64 Grocott colorations) which were all negative. Only three patients $(4 \%)$ had a positive PCR with a cycle threshold range of 35.5-37. All were classified as Pneumocystis colonization. Two of them did not have any pre-existing risk factors besides 10 days of corticosteroid for COVID-19 and had a negative $\beta$-D-glucan. One patient with liver transplantation and long-term corticosteroid therapy and calcineurin inhibitor treatment had a positive PCR with only one low titer positive $\beta$-D-glucan (178 pg/mL); he was classified as Pneumocystis colonization, because his state improved without Trimethoprim-sulfamethoxazole treatment.

These findings are consistent with the finding of Alanio et al. [4] who found 9.3\% of Pneumocystis positive RT-PCR. We would like to highlight that when discussing Pneumocystis jirovecii it is important to differentiate Pneumocystis pneumonia and Pneumocystis colonization. In the study of Alanio et al., none of the ten patients had Pneumocystis pneumonia (PCP) criteria (i.e. positive direct examination for proven PCP or positive RT-PCR with 2 positive $\beta$-Dglucan for possible PCP [5]) and were identified as "carriers". Only 4 of them were treated with prophylactic dose of co-trimoxazole without evident effect on mortality.

All these data are consistent and the statement that Pneumocystis pneumonia (PCP) risk is low in COVID-19 ARDS patients is still true in the "era of dexamethasone", whereas colonization seems to be higher than in the first wave but not associated with mortality. However, further studies are needed to explore if colonized patients have a higher risk of mortality.

\section{Abbreviations monia; ICU: Intensive care unit. \\ Acknowledgements \\ None. \\ Authors' contributions \\ Funding \\ None. \\ Availability of data and materials \\ Not applicable.}

ARDS: Acute respiratory distress syndrome; PCP: Pneumocystis jirovecii Pneu-

$\mathrm{PMH}_{1} \mathrm{SM}, \mathrm{DDB}$ designed the paper. All authors participated in drafting and reviewing. All authors read and approved the final version of the manuscript.

\section{Declarations}

Ethics approval and consent to participate

Not applicable.

\section{Consent for publication}

Not applicable.

\section{Competing interests}

The authors declare to have no competing interests.

\section{Author details}

${ }^{1}$ ICU Department, Centre Hospitalier Universitaire Brugmann-Brugmann University Hospital, ULB University, Place Van Gehuchtenplein, 4, 1020 Brussels, Belgium. ${ }^{2}$ ICU Department, Centre Hospitalier Universitaire Brugmann, Brussels, Belgium. ${ }^{3}$ ED Department, Centre Hospitalier Universitaire Brugmann, Brussels, Belgium. ${ }^{4}$ ICU Department, Centre Hospitalier Universitaire Brugmann, ULB, Brussels, Belgium.

Received: 8 December 2021 Accepted: 10 December 2021

\section{References}

1. Razazi K, Arrestier R, Haudebourg AF, et al. The COVID PCP group. Pneumocystis pneumonia risk among viral acute respiratory distress syndrome related or not to COVID 19. Crit Care. 2021;25(1):348. https://doi.org/10. 1186/s13054-021-03767-3.

2. Abdoli A, Falahi S, Kenarkoohi A. COVID-19-associated opportunistic infections: a snapshot on the current reports. Clin Exp Med. 2021. https:// doi.org/10.1007/s10238-021-00751-7.

3. Chong WH, Saha BK, Chopra A. Narrative review of the relationship between COVID-19 and PJP: does it represent coinfection or colonization? Infection. 2021. https://doi.org/10.1007/s15010-021-01630-9.

4. Alanio A, Dellière S, Voicu S, Bretagne S, Mégarbane B. The presence of Pneumocystis jirovecii in critically ill patients with COVID-19. J Infect. 2021;82(4):84-123. https://doi.org/10.1016/j.jinf.2020.10.034.

5. Donnelly JP, Chen SC, Kauffman CA, Steinbach WJ, Baddley JW, Verweij PE, et al. Revision and update of the consensus definitions of invasive fungal disease from the European Organization for Research and Treatment of Cancer and the Mycoses study group education and research consortium. Clin Infect Dis. 2019;71:1367-76.

\section{Publisher's Note}

Springer Nature remains neutral with regard to jurisdictional claims in published maps and institutional affiliations. 